811.163.41'366.55

https://doi.org/10.18485/sj.2017.22.1.10

САЊА М. КУЉАНИН ${ }^{*}$

Филозофски факултет Пале

Катедра за србистику
Оригинални научни рад

Примљен: 14. 10. 2016.

Прихваћен: 15. 12. 2016.

\title{
ОДНОС СУПЕРЛАТИВА И НАДСУПЕРЛАТИВА У САВРЕМЕНОМ СРПСКОМ ЈЕЗИКУ
}

\begin{abstract}
У раду се, на формално-семантичком плану, анализира однос суперлатива и надсуперлатива. Синтетички мофолошки суперлатив, као дио трочлане компарацијске парадигме, највиши степен особине или својства неког појма изражава само у међуодносу са осталим појмовима, тако да квалификација исказана суперлативом на мора увијек подразумијевати изразито висок степен заступљености садржаја придјева или прилога у односу не неку уобичајену норму. Међутим, формама надсуперлативног значења увијек се исказује изразито висок, максимални степен особине, због чега је он експресивнији и семантички богатији.
\end{abstract}

Кључне ријечи: компарација, суперлатив, надсуперлатив, елатив, ексцесив.

\section{1. УВОД}

Општепознато је да је компарација граматичка категорија својствена квалитативним придјевима и прилозима хомоформним с придјевима средњег рода, заснована на степену заступљености неке особине именичких појмова, који се пореде, предмета или бића који посједују исту особину у неједнакој мјери (в. Ковачевић и др. 1991: 37; Станојчић, Поповић 1997: 87; Силић, Прањковић 2005: 138). Компарација је граматикализована трочлана парадигма, у оквиру

*sanja.kuljanin@ffuis.edu.ba 
које се различит степен исте особине изражава посебним обликом придјева / прилога, и то тако „што основни придев (позитив) означава основну, позитивну особину; први ступањ (компаратив) казује особину у вишем степену од оне која се означава основним придевом; а други ступањ (суперлатив) показује да појам који он одређује - означену особину има у највишем степену између свих појмова с којима се пореди" (Стевановић 1991: 253). У овом раду анализираћемо само један облик компаративне парадигме - суперлатив, релативни, којим се у оквиру диферентивног односа појмова који се пореде једном од њих приписује највиши степен заступљености неке квалификације, и апсолутни, којим је неки појам оквалификован веома високим степеном заступљености дате особине, у оквиру конструкције без поредбеног елемента. Циљ рада је да се, на формално-семантичком плану, укаже на однос суперлативне форме и облика којима се изражавају надсуперлативна значења, тј. веома висок или изразито висок степен заступљености неке квалификације исказане придјевима или прилозима у оквиру апсолутне компарације.

\section{2.СУПЕРЛАТИВНО ЗНАЧЕњЕ}

У граматичкој литератури најчешће се говори само о релативној компарацији, која подразумијева експлицирање оба компарацијска члана, и оног који се пореди (поређени члан или поређеница) и оног са којим се пореди (поредбени члан или поредбеница) ${ }^{1}$, тако да се и наводе, када је ријеч о суперлативу, његове диферентивне конструкције, гдје је први члан или поређеница општепознати морфолошки синтетички суперлатив, који се гради додавањем префикса или суперлативне ријечце $\operatorname{coj}^{2}{ }^{2}$ на облик компаратива датог придјева / прилога, а други члан поређења ${ }^{3}$ „изражава се или формом од+генитив, или формом

${ }^{1}$ Називе поређеница и поредбеница уводи М. Ковачевић у свом раду Степеновање у оквиру суперлатива (2009: 28).

${ }^{2} \mathrm{Haj}$ - је „формант сасвим посебне врсте, будући да не ствара нове речи као други префикси, него обавља чисто граматичку функцију грађења суперлатива, а он је готово неограничено продуктиван, јер се употребљава за све описне придеве, али подложан посебном граматичком ограничењу управо због тога што се спаја само с обликом компаратива" (Клајн 2002: 215). С. Бабић (1986: 330) тврди да се у „публицистичком језику нај- употребљава и као именички префикс, наводећи примјере (писане углавном са цртицом) нај-браћа, нај-дар, нај-маневар, најплаћа, нај-филм и још неколико сличних. У фамилијарном односу могуће су реченице типа „за мене је ово нај-филм”, али то је слободно стилско средство, које своју афективност заснива управо на анонимној употреби придјевског префикса уз именицу, међу глаголским (највољети и најжељети) и прилошким (најпослије, највећма итд.)".

${ }^{3}$ У граматичкој литератури, на основу критеријума испољености особине у другом члану поређења, разликује се основни, ужи и најужи суперлатив. Значење основног суперлатива заступљено је у конструкцијама у којима се не истиче степен испољености особине у другом члану поређења, нпр. Она је најљепша у разреду; Они су најуспјешнији у тиму. Ужим суперлативом „истиче се да и сви други чланови у поређењу имају врло изражену особину која се првом 
међу+инструментал”, а може се реализовати и „у форми између+генитив” (Марко је најстарији од њих / међу њима / између њих)” (Ковачевић 2003: 27). Осим тога, „у поредбеној конструкцији може се именовати појам који означава скуп из којег се нешто одабрано истиче: Петар је најстарији човек у селу, а без навођења ове ситуационе конструкције придјев се може везати, како смо већ рекли, предлогом међу са именом појма са којим се пореди, при том је важно да се име појма налази у множини, па бисмо онда имали овакву конструкцију: Петар је најстарији међу сељацима" (Мразовић 2009: 323-324).

Самим тим што се говори о релативној компарацији као граматичкој категорији придјева (прилога), конкретно о облику морфолошког, синтетичког суперлатива, оствареног у поредбеној конструкцији, степен особине или уопште неке квалитативности који се приписује поређеници највиши је само у међуодносу са осталим појмовима у поредбеници, тако да ни у једном ни у другом поредбеном члану та квалитативност не мора бити заступљена у пуном или високом степену у односу на неку уобичајену норму, а на то утиче семантика самих придјева (и одговарајућих прилога). У вези с тим постоји и класификација придјева, заснована на тезама Ане Вјежбицке (Wierzbicka 1971), коју је урадио А. Мељчук (1994: 102-103), а из које ћемо овдје издвојити двије групе: 1. параметарски придјеви, који се могу односити на три типа комуникативне ситуације: а) суперлатив (као и компаратив) дозвољавају употребу позитива на оба објекта поређења (нпр., ако кажемо „Марко је највиши од своје браће / међу својом браћом", можемо их све окарактерисати као високе, с тим да је у поређеници, тј. код Марка, израженији степен заступљености садржаја придјева висок); б) суперлатив дозвољава употребу позитива само на први објекат (нпр. у наведеној реченици можемо само први објекат, тј. Марка, одредити као високог, а остале не); в) суперлатив не дозвољава употребу позитива ни према једном од објеката који се пореде (ниједном од њих не можемо приписати својство 'висине', што значи да ниједан од њих, према некој уобичајеној норми, није висок, тј. ниски су, али се жели нагласити да је Марко највиши међу њима); 2. придјеви оијене (естетске, моралне и емоционалне), за које је карактеристично да суперлатив претпоставља да је особина изражена обликом позитива својствена и једном и другом објекту поређења. Ако кажемо да је Марко најтврдоглавији од своје браће, сваком члану поређења приписујемо својство, особину 'тврдоглавости', али у таквом релативном поређењу један од њих одређену особину посједује у већој мјери од појмова

члану поређења (елементу или делу тога скупа) приписује као најизраженија, нпр. То су били најпознатији међу познатима" (Пипер идр. 2005: 856). Други члан поређења у оваквим конструкцијама може бити изражен инструменталом с предлогом међу (као у наведеном примјеру) или локативном конструкцијом, нпр. У тој групи даровите дјеце она је била најдаровитија. У конструкцијама са најужим суперлативом и сви други чланови у поређењу имају суперлативно изражену особину, али се првом члану приписује као најизраженија, тако да у тим конструкцијама имамо двоструки суперлатив, нпр. Такмичиле су се најљепме међу најљепиима (Исто: 856). 
с којима се по тој особини пореди. Као што су показали претходни примјери у вези са семантичком класификацијом придјева, суперлатив не подразумијева увијек заступљеност својства у много већој мјери од неке уобичајене норме, тј. особина исказана релативним суперлативом не мора уопште подразумијевати висок степен заступљености садржаја придјева или прилога ни код једног од чланова који се пореде,

Друкчији је случај са апсолутним суперлативом, који се остварује „кад се у реченици не појављује појам с којим се пореди особина изражена придевом нити се такав појам претпоставља" (Мразовић 2009: 324), тј. апсолутно поређење се остварује „када се у реченици не наводи појам с којим би се у количини особине изражене придјевом поредио експлицирани појам (као нпр.: Ово је стара / старија / најстарија тврђава) (Ковачевић 2009: 28). Квалификација исказана апсолутним суперлативом увијек подразумијева веома висок степен садржаја придјева или прилога, семантички близак оном релативном суперлативу којим је исказан висок степен квалификације својствен свим члановима поређења између којих један има дато својство изражено више од осталих или када појам у поређеници посједује неко својство заиста заступљено у високом степену у односу на уобичајену норму или стандард. Апсолутни суперлатив формално се изражава као и релативни, додавањем суперлативне ријечце нај- на облик компаратива, (наглашавамо, у таквој компарацијској конструкцији не наводи се поредбени члан, нпр. најљубазније замолити, најсрдачнији поздрав, најњежнији пољубац и сл.), али се изражава и придјевском / прилошком синтагмом чији је конститутивни члан лексема с градационим значењем, као нпр. врло, веома, јако, с интегралном семом 'велики степен', те лексеме попут страшно, страховито, невјероватно и сл., које такође представљају градационе допуне уз позитив придјева или прилога, али осим изражавања великог степена особине или својства оне у исказ уносе и додатне, експресивније семантичке компоненте садржане у примарном значењу тих лексема (Куљанин 2012: 155-176). Дакле, на формалном плану остварује се и творбено и лаксички, као што се реализује још један вид апсолутног изражавања квалификације неког појма али семантички на степену вишем од суперлатива. Наиме, постоје и форме за исказивање изразито високог степена одређене квалитативности, и синтетичке и описне, које надмашују суперлативно значење, тј. имају улогу појачаног суперлатива, надсуперлатива или елатива.

\section{3. НАДСУПЕРЛАТИВНО ЗНАЧЕЊЕ}

У различитим комуникационим ситуацијама, при свакодневном вредновању и процјењивању особина или својстава, морфолошки синтетички 
релативни суперлатив, као дио трочлане компартивне парадигме, није увијек довољан за прецизно и нијансирано изражавање максималне заступљености неке квалификације, а ни за субјективност и експресивност у исказу. Зато можемо рећи да су облици тростепене компаративне парадигме често затворен и ограничен систем, јер релативност семантичких вриједности придјева, с обзиром на њихову контекстуалну актуелизацију и семантичке модификације, и непостојање лексикализованих прелаза међу категоријама, граничним и прекограничним случајевима, не могу покрити два компаративна степена, компаратив и суперлатив, па за такво квалификовање у српском језику постоје и други начини изражавања, који се реализују на творбеном и лексичко-синтаксичком плану.

3.1. За експлицирање веома високог степена заступљености неког својства, у комуникационим ситуацијама када говорно лице, на основу субјективног виђења, некоме или нечему жели приписати максимални степен особине без икаквог поређења првенствено служе надсуперлативне или елативне форме, које су семантички богатије од суперлатива, тј. подразумијевају виши степен у градацији неке особине или својства. Семантичка инваријанта елатива односно надсуперлатива остварује се и на префиксалном и на лексичком нивоу. На творбеном, префиксалном плану елатив се реализује у својој основној синтетичкој форми - префикс пре+позитив, што показују сљедећи примјери:

Остали су пресрећни и скачу од радости (Вучковић 2004: 45); Са осећањем да су нападнути од прејаке војне силе... (Вучковић 2004: 85); Вјерујем да ће тада престати да ме у сну посјећује и да ће напустити моје сјећање, ионако преоптерећено бројним сувишностима (Вучковић 1998: 139); Хтела сам превише и прејако! (novosti.rs/vesti/sport.); Изнер прејак за Лајовића у Ници (novosti.rs/vesti/sport); Хркање може да буде последица алергије, умора, прекомерне телесне тежине... (telegraf.rs/zivot-i-stil); Ако клима хлади прејако, прехлада долази прелако (medisadria.hr); ,iРad” забрањен због прејаког сигнала (klix.ba/vijesti/svijet); Како заштитити домаћу производњу од „прејаког удара” конкуренције? (klix.ba/biznis); Немице прејаке за Српкиње (dnevnik.rs/sport); Olimpijske prvakinje prejake za Hrvatice (tportal.hr/sport); Руски план прекида ватре у трајању осам сати у четвртак како би се омогућило цивилима и побуњеницима да напусте тај сиријски град стиже прекасно и прекратко је (vecernji.hr/svijet).

У наведеним примјерима презентовали смо надсуперлативну, елативну употребу префикса пре-, који је најтипичнији префикс за појачавање придјевског / прилошког значења. Такви придјеви, како каже М. Стевановић (1970: 429), „казују особину основног придева изражену у одвећ великом степену”. А. Белић у Грађењу речи о префиксацији придјева говори као о средству за изражавање ,афективних значења субјективне оцене”, наводећи између осталих и префикс пре- (презрео - сувише зрео) (Белић 1949: 195-196), а Т. Маретић у Граматици хрватскога или српскога књижевног језика, говорећи о придјевима сложеним, како каже, са „предлогом” пре- наводи да они значе „својство у највећој мјери” (Маретић 1963: 387, 398-399). 
У свим примјерима елативом се изражава „степен преко нормале или допуштене мере" (Мразовић, Вукадиновић 1990: 274), тј. најмање једна семантичка компонента више у градацији особине (Ковачевић 2003: 26). Такву семантику овај степен заступљености особине или својства експлицира, како смо видјели, употребом префикса пре-, који испред облика позитива семантички модификује лексичку основу и спецификује је у одређеном правцу и као семантички испуњен елемент изражава интензитет (Радовић Тешић 2004: 220). У Енциклопедијском рјечнику лингвистичких назива Р. Симеона (1969: 296) елатив је „назив који се каткада даје апсолутном суперлативу да би се разликовао од суперлатива у правом смислу ријечи, тј. релативног суперлатива; према томе значи неко својство у врло великом ступњу без икаква поређења. Термин суперлатив, напротив, с обзиром на своју употребу у граматици, упућивао би на поређење, и отуда није погодан да означи пре- нити друге 'појачајне' префиксе осим нај-'.

У претходно наведеној групи сви примјери са надсуперлативним значењем исказани су синтетичким елативом (пре+позитив), међутим, елативно значење може бити и перифрастички изражено - употребом елативног прилога превише уз позитив придјева или прилога, као нпр.:

Запосела га је маса, али не у превише густим /прегустим/ таласима (Вучковић 2004: 45); Уколико претерано често морате да пуните батерију на вашем паметном телефону, кривац за то је Фејсбук апликација (srbijadanas.com). На трибини у Енглеској пре пар година филозоф Пол Тејлор рекао је да је главни проблем медија што себе схватају превише озбиљно (mirc.rs).

Појачајни, елативни префикс пре- и семантички еквивалентна лексема превише могу бити различито контекстуално маркирани, али се елативна компонента јасније потцртава употребом лексеме него префикса, јер је лексема обиљежена семантемом, а префикс семантичком компонентом као дијелом семантеме.

Префикс пре- уз позитив, у оквиру апсолутне компарације, дакле, уноси значење прекомјерног степена, степена преко крајње границе, и тако, у зависности од контекста, говорне ситуације и комуникативног циља служи за изражавање појачане или најјаче интензивности, са различитим значењима и нијансама значења. За разлику од синтетичког морфолошког нај- суперлатива, овај облик може имати и обиљежје одређене семантичке диференцијације, јер надсуперлатив с префиксом пре- изражава максимално појачан интензитет неког својства, али придјеви и прилози с овим префиксом могу изражавати и семантичку специфичност ексцесивности, када пре- означава прекомјерност, претјераност и исказује став говорног лица у вези с тим, уз одреднице више него што треба, вище него што је пожељно, више него што је дозвољено и сл., у сваком случају ријеч је о претјеривању и прекомјерности без обзира на 
то да ли је самантика придјева позитивна или негативна. Семантичка специфичност ексцесивности, у оквиру семантичке категорије градуелности, јесте модална компонента (Пипер и др. 2005: 866). Ту се семантичка категорија градуелности пресијеца с категоријом модалности, јер се осим интензитета дате особине изражава и оцјена о појави која се степенује, тј. оцјењује се степен одступања од испољености неког својства (нпр. преухрањен „ухрањен више него што је потребно”). Тако у нашем примјеру Руски план прекида ватре у трајану осам сати у четвртак како би се омогућило цивилима и побуненицима да напусте тај сиријски град стиже прекасно и прекратко, надсуперлативи прекасно и прекратко имплицирају ексцесивно значење: прекасно - требало је раније, прекратко - није довољно, треба много више и сл. То одступање, карактеристично за ексцесивност, као нарушавање екплицитне или имплицитне норме, може се сматрати неуобичајеним или непожељним. Ексцесивност се, дакле, „значењски односи на граничне, тачније 'прекограничне' случајеве испољавања неке особине, својства, стања и сл. са становишта прекорачења могућности, потребе или обавезе, (превише, одвише, одвећ, претерано, премало, потхрањен, надљудски ...; или синтаксичка ексиесивност, нпр. преко мере, изнад могућности, испод очекивања...) (Пипер и др. 2005: 865). Ексцесивима може бити означена и позитивна и негативна особина, али се у сваком случају могу парафразирати прилозима сувише, превише (превелик = сувише велик), или конструкцијом компаратив + него што (би) треба(ло) (превелик = већи него што треба, прекратак = сувише кратак, краћи него што треба и сл. Елатив и ексцесив формално су исказани истим облицима, јер у ствари заступљеност ексцесива није праћена изразитијим формалним обиљежјем, па у неким случајевима само контекст може диференцирати ексцесивност и елативност (Пипер 2003: 170).

3.2. Још један начин творбе надсуперлатива јесте помоћу језичких елемената страног поријекла, као што су супер, екстра, ултра, мега и др. Најфреквентнији је супер, који се јавља и самостално и као префикс / префиксоид и именичких и придјевских ријечи, чија је архисема 'више од суперлатива'. Као први дио у новонасталој ријечи „супер- (лат.) значи: највиши, врховни, горњи, који је изнад нечега, нпр.: Совјетског милијунаша не може наћи ни народни комесаријат са својим суперјаким пореским апаратом” (РМС 1990: 91). Битна особина префикса супер-, као и осталих префикса страног поријекла које смо претходно навели, јесте „да даје дозу уопштавања и апстракције, што може да замени цео синонимни низ детерминатора који би у српском могли да спецификују или експресивно маркирају поједине основе” (Радовић-Тешић 1996: 301).

Да бисмо презентовали овај вид надсуперлативног значења, издвојићемо овдје само супер као најфреквентнији префикс / префиксоид или као индеклинабилну лексемау. И у литератури је већ указано на веома фреквентну употребу 
ове језичке јединице, нпр.: супербогат, суперлак, супертајни, суперлуксузан... (Бабић 1986: 446), суперженствен, супернадарен, супермодеран... (Клајн 1992). Њоме се не модификују само придјеви, у смислу изражавања изузетно, максимално заступљеног њиховог садржаја, наиме, посљедњих година, посебно у разговорном и публицистичком стилу, као и други елативни префикси (хипер-, екстра-, ултра-), супер- се комбинује с готово неограниченим бројем страних и домаћих именица (Клајн 2002: 203): супербогаташ, супермушкарац, суперљепотица, супернебодер, супербисер, суперзвијезда, суперлига, суперфинале, суперспектакл и др. У том случају тај префикс с елативним значењем не изражава само надсуперлативну заступљеност једне квалификације, он у ствари обједињује читав низ особина, такође заступљених у изузетно високом степену, којима се у том контексту жели спецификовати одређени појам.Тако нпр. суперавијачија подразумијева да је ријеч о авијацији која је истовремено најсавременија, изузетно добро опремљена, сигурна, прецизна и сл. Илустроваћемо употребу језичког елемента супер (-) сљедећим примјерима:

А тај Први мај, комуњарски празник, памтим само као супер дан да се добро испавам (Глас јавности, 1338, 5). Хале је супер особа (Блиц, 3911, 36); To zato što je baš totalno super ... (poljanakonfuzija. blogger.ba); Superbakterije su i više super nego što se mislilo (tportal.hr); I onda sam se sjetio, ali to je zadnji rok i to se mora proći xD. I onda mi je bilo malo manje super (rasprave.fizika.org); Antonija je bila super, a sad bismo u duhu zajedništva trebali reći da su zapravo svi bili super. Dobro, neki su bili više super, neki manje super (mojmag.com); Delikatese u kojima ste uživali ovih dana su super stvar. Malo je manje super stvar činjenica da danas možda nešto teže navlačite omiljene traperice (kupime.hr); Ovi ljudi nemaju lošu pjesmu. Masa bendova ima super, manje super, loše, bezvezne pjesme, ali Oktobar ima ekstra svaku pjesmu (youtube.com).

Примјери су илустровали веома разноврсну употребу ове јединице која имплицира надсуперлативно значење. Занимљиво је да се она појављује и као индеклинабилни придјев у конструкцији перифрастичке компарације (више cynep, мање супер). Овакви примјери пронађени су на интернету и можемо их сврстати само у оквире разговорног стила, јер их у књижевноумјетничком стилу нисмо забиљежили .

Појачана фреквентност овог префикса (лексеме), посебно у публицистичком и разговорном стилу, управо потиче од велике способности апстракције кад се овај елемент употребљава испред именице и када се жели неком појму приписати неко својство у апсолутном надсуперлативном значењу.

Дакле, супер, било да је лексема било да је префикс, имплицира значење високог степена неке особине или својства, тј. увијек је ријеч о високом нивоу или врхунском квалитету, о савршеном, изузетном, веома великог домета и значаја и сл. Захваљујући фреквентној употреби, супер је „стекло особине непроменљивог придева, углавном у омладинском жаргону, са значењем 'сјајан, изванредан'; употребљава се и у предикату (ручак је био супер), може постати 
и прилог (Ово сте супер урадили), а као именица представља скраћење од супербензин" (Клајн 2002: 203).

3.3.Функцију елативног, надсуперлативног или прекомјерног значења имају и лексеме у оквиру придјевских / прилошких синтагми као што су одвише, одвећ, (и)сувише, претјерано, надасве, енормно, екстремно и др., с "интегралном семом прекомерног степена, степена преко крајње границе која је субјективно одређена" (Ристић 1990: 116). И њима се исказује постојање квалификације изражене придјевом / прилогом у врло великом, прекомјерном степену, без икаквог поређења. У зависности од контекста, говорне ситуације и комуникативног циља одговарајуће придјевске и прилошке структуре служе за изражавање појачане или најјаче интензивности, а у оквиру тога и оне могу изражавати или ексиесивност или појачану интензивност, односно елативност. „Главна семантичка специфичност ексцесивности у оквиру семантичке категорије градуелности јесте у градуелној локализацији спољашњом границом локализатора (,изнад” или „испод” локализатора) и у обавезности модалне компоненте у значењима ексцесива" (Пипер и др. 2005: 866).

Значење прекомјерности, тј. степена преко крајње границе, потврђује и рјечничко одређење лексема које смо овдје издвојили : одвише - "преко (сваке) мере, сувише, одвећ" (РСЈ 2007: 856); сувише - "одвећ много, превише ..." (PCJ 2007: 1283).

Ово ће бити ... одвише срећно (РМС 4, 27); Вечерас је била одвише уморна (РМС

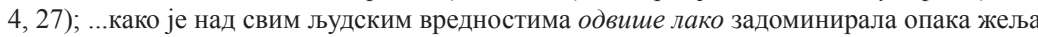
за влашћу (Којовић 2007: 22); ...спознавши одвише касно како сам ипак живео у једној трагичној, мрачним страстима растрзаној земљи (Којовић 2007: 23).

Осим што се у претходним примјерима изражава прекомјеран степен неке особине или својства, прилогом одвище уз прилоге лако (начински) и касно (временски), може се осјетити и ауторова оцјена тог степена у смислу ексцесивности, и то као ексцесивност потребе: одвише лако задоминирала жеља за влашћу „више него што је потребно и више него што је пожељно”; спознавщи одвише касно, „касније него што је потребно, требало је спознати раније”.

И у реченици с прилогом (u)сувише изражена је ексцесивност: сувише споро - спорије него што би требало, ито није пожељно; сувише слаб - слабији него што треба, ито није пожељно:

Можда ове реченице не клизе баш најбоље, можда је ово писмо сувише споро, можда сам ја сувише слаб за овај крст који сви носимо ... (Пржуљ 1998: 58).

Рјечничке одреднице прилога одвећ, „претерано, сувише” (РМС 4: 26), потврђују прекомјерност степена заступљености својства исказаног придјевом (строг) и прилозима (радикално, дуго, рано). У примјеру одвећ радикално изражена је и ексцесивност у смислу непожељности претјераног степена: 
Знам да ће многима овакав став зазвучати одвећ радикално (превише / претјерано радикално, радикалније него штоо треба, него што је пожељно) (Блиц, 2801, 6).

Прилози претјерано и надасве у рјечничком одређењу такође имају компоненту прекорачења одређене норме: надасве - "више од свега, изнад свега” ; претерано - „прил. прекомерно, превише” (РМС 1969: 514):

... ни за једну (годину) се не би могло рећи да је претерано добра (Блиц, 2834, 32); У дому није било претјерано забавно (превише забавно) Крл. Она је била претерано бледа (превише бледа) и бела девојчица. Макс. (РМС, 1002).

У примјерима с прилогом претјерано (претерано добра, претјерано забавно) исказан је прекомјеран степен садржаја лексема добра и забавно, с елативним значењем, тј. изражава се појачан интензитет тих квалификација, док је у посљедњој реченици исказана ексцесивност: претерано бледа-сувише бледа, ито није добро, није пожељно.

Сложени прилог (предлог + замјеница) надасве (изнад свега) уз придјев добар такође изражава прекомјерност особине садржане у позитиву придјева, тј. њен високи интензитет, са елативним значењем. И просторна иконичност, концептуализација изнад уобичајене норме, на врху скале интензитета, потврђује надсуперлативно значење које се постиже овом градационом лексемом, чему доприноси приједлог (из)над, из чијег се основног просторног значења развило појачајно значење - који је изнад по квалитету, степену, интензитету:

Срео сам успут свог кројача, увек веселог старијег човека ... упорног и надасве доброг мајстора свог заната (Којовић 2007: 24); Ето живота за којим чезнем: пронаћи једно тихо, скровито и надасве скромно место ...

Лексеме екстремно и енормно својом семантичком структуром основних облика већ указују на надсуперлативност. Прилози екстремно и енормно изражавају изузетно висок степен заступљености особине или својства исказаних придјевом или прилогом испред којих стоје, уз сљедеће рјечничко одређење: „екстремно прил. на екстреман начин, крајюе, претерано” (РСЈ 2007: 349). Потпуније значење наведено је под одредницом екстреман као придјев: „екстреман, -мна, -о, а) који достиже крајюи, највиши степен, који иде до крајюих граница, претеран, који заступа радикалне ставове и мере ... б) највећи, односно најмањи могућни, гранична, ексремна вредност" (РСЈ 2007: 349); ,енормно прил. претерано, огромно (енорман, -мна,-о, претерано велик, огроман, голем, дивовски)" (РСЈ 2007: 356).

Екипа која има високог и екстремно доброг Жигића била је изузетно моћна (Блиц, $2801,17)$; Талас врућине, са екстремно високим температурама, изазвао је здравствене тегобе код многих људи (Вечерње новости, 30. 11. 2004, 26); ... али, пре свега, енормно су богате (Блиц, 3412, 9); ... како сам ипак живео у једној трагичној, мрачним страстима растрзаној земљи, склоној кавгаџијству и свакаквим поделама, где се енормно лагало и у којој нико и никоме у души није веровао (Којовић 2007: 23). 
Експлицирање надсуперлативног значења лексемама с интегралном семом прекомјерног степена, слично је изражавању таквог степена помоћу појачајног, елативног префикса пре-, али се елативна компонента, како је већ речено, јасније потцртава употребом лексеме него префикса, јер је лексема обиљежена семантемом, а префикс семантичком компонентом као дијелом семантеме.

Број градационих лексема које се јављају у оваквим конструкцијама није ограничен и непрекидно се повећава, јер је „градација јако подложна утицају прагматских фактора. Тако се систем градације налази у стању непрекидне реорганизације" (Ристић 2009: 141). Зато су овдје наведене градационе лексеме само илустрација оваквог начина интензивирања, јер број лексема које се јављају о оваквим конструкцијама много је већи и с обзиром на контекст, комуникациону ситуацију, став и намјеру говорног лица имају различите прагматске и функционалностилске садржаје.

\section{4. ЗАКЉУЧАК}

Висок степен заступљености особине или својства неког појма у српском се језику може изразити суперлативом и надсуперлативом. Њихов однос може се посматрати и на формалном и на семантичком плану. Морфолошким синтетичким суперлативом (нај+позитив), оствареним у поредбеној конструкцији, тј. када је ријеч о релативној компарацији, степен особине или уопште неке квалитативности који се приписује поређеници највиши је само у међуодносу са осталим појмовима у поредбеници, тако да ни у једном ни у другом поредбеном члану та квалитативност не мора бити заступљена у пуном или високом степену у односу на неку уобичајену норму. На то утиче семантика самих придјева (и одговарајућих прилога), па се заиста висок степен квалификације подразумијева само у комуникативној ситуацији када сви чланови поређења посједују својство изнад неке уобичајене норме, а код једног од њих оно је изражено више него код осталих. Истом формом (нај+позитив) увијек се исказује висок степен особине у ситуацији када изостане навођење релационог елемента, а самим тим и поредбенице, тј. када је ријеч о апсолутном суперлативу, који се изражава и придјевском / прилошком синтагмом чији је конститутивни члан лексема с градационим значењем, као нпр. врло, веома, јако, с интегралном семом 'велики степен'.

У оквиру апсолутног значења, творбено и лексички, реализују се и форме за исказивање изразито високог, максималног, прекомјерног степена одређене квалитативности, и синтетичке и описне, којима се надмашује суперлативно значење, те их означавамо као елатив или надсуперлатив. Овај облик се остварује помоћу префикса пре- и префикса / префиксоида супер- (на творбе- 
ном плану сличан је релативном и апсолутном суперлативу: нај+позитив), а може се исказати и лексички, као и апсолутни суперлатив (веома, врло, јако $u$ $\partial p$. + позитив), помоћу лексема које у придјевску / прилошку синтагму уносе значење прекомјерног степена, степена преко крајње границе, као што су одвише, одвећ, (и)сувише, претјерано, надасве, енормно, екстремно и др. На семантичком плану, осим исказивања надсуперлативне заступљености неког својства, овај облик, за разлику од суперлатива, има и обиљежје одређене семантичке диференцијације, јер елативни префикс пре- изражава максимално појачан интензитет неког својства, али придјеви и прилози с овим префиксом могу имплицирати и семантичку специфичност ексцесивности, када пре- означава прекомјерност, претјераност и исказује став говорног лица у вези с тим, уз одреднице више него ито треба, више него ито је пожељно, више него ито је дозвољено и сл., у сваком случају ријеч је о претјеривању и прекомјерности без обзира на то да ли је самантика придјева позитивна или негативна.

У овом раду указали смо на богатији и експресивнији садржај надсуперлатива и облике његове употребе. Детаљнија семантичка анализа надсуперлативних начина изражавања захтијевала би много обимнији корпус, с великим бројем примјера, што превазилази оквире једног рада.Тако ће ова проблематика вјероватно бити тема даљих истраживања, у којима ће се издвојити прецизнија значења ових али и многих других форми изражавања надсуперлативне семантике.

\section{ИЗВОРИ}

\section{а) књижевноумјетничка дјела}

Вучковић 2004: Радован Вучковић, У невремену, Београд: Народна књига / Алфа.

Вучковић 1998: Радован Вучковић, Приче сарајевских избјеглица, Београд: Свет књиге.

Којовић 2007: Вељко Којовић, Крвава кошуља сарајевска, Бања Лука: Бесједа.

Пржуљ 1998: Жељко Пржуљ, Браћа по улиции, Панчево: Знамење, Панчево.

\section{б) новине}

Блиц, дневне новине, Београд;

Вечерње новости, дневне новине, Београд;

Глас јавности, дневне новине, Београд. 


\section{ЛИТЕРАТУРА}

Бабић 1986: С. Бабић, Творба ријечи у хрватском књижевном језику, Загреб: ЈАЗУ - Глобус.

Белић 1949: А. Белић, Савремени српскохрватски књижевни језик, 2. део: Наука о грађењу речи, Београд.

Клајн 2002: И. Клајн, Творба речи у савременом српском језику. Део 1, Слагање и префиксација, Београд: Завод за уџбенике и наставна средства, Институт за српски језик, Нови Сад: Матица српска.

Клајн 1992: И. Клајн, Речник нових речи, Нови Сад.

Ковачевић 2009: М. Ковачевић, Експресивне синтагме са суперлативним значењем, у: Огледи из српске синтаксе, Београд: Друштво за српски језик и књижевност.

Ковачевић 2003: М. Ковачевић, Перифрастичка компарација у српском књижевном језику, у: Граматичке и стилистичке теме, Бања Лука: Књижевна задруга.

Ковачевић и др. 1991: М. Ковачевић, Ј. Баотић, М. Окука, Ч. Ребић, Наш језик, уибеник сх/хс језика за 2. разред средњег усмјереног образовања, Сарајево: Свјетлост, Завод за уџбенике и наставнс средства.

Куљанин 2012: С. Куљанин, Перифрастичке форме компарације у савременом српском језику, необјављена докторска дисертација, одбрањена 2012. године, Филозофски факултет Пале.

Маретић 1963: T. Maretić, Gramatika hrvatskoga ili srpskoga književnog jezika, Zagreb: Matica hrvatska.

Мељчук 1994: I. Mel’čuk, Cours de morphologie générale, Vol. II, 2-ème partie: Significations morphologiques, Montréal: CNRS Ed.

Мразовић 2009: P. Mrazović, (u saradnji sa Z. Vukadinović), Gramatika srpskog jezika za strance, Sremski Karlovci, Novi Sad: Izdavačka knjižarnica Zorana Stojanovića.

Пипер и др. 2005: Предраг Пипер, Категоријални комплекс квалификације и квантификације, у: П. Пипер, И. Антонић, В. Ружић, С. Танасић, Љ. Поповић, Б. Тошовић, Синтакса савременог српског језика. Проста реченииа, Београд - Нови Сад: Институт за српски језик САНУ, Београдска књига, Матица српска, 830-868.

Пипер 2003: П. Пипер, Степеновање у граматици и речнику, Зборник Матице Српске за славистику, бр. 61, 59-79. 
Радовић-Тешић 2004: М. Радовић-Тешић, Богаћење лексике префиксацијом, Српски језик IX/1-2, Београд: Научно друштво за неговање и проучавање српског језика, 219-227.

Радовић-Тешић 1996: Милица Радовић-Тешић, О лексичким позајмљеницама, Зборник радова са научног скупа Стране речи и изрази у српском језику са освртима на исти проблем у језицима национални мањина, Суботица - Београд.

Ристић 1990: Стана Ристић, Начински прилози у савременом српскохрватском језику (лексичко-граматички приступ), Библиотека Јужнословенског филолога, нова серија, књ. 9, Београд.

Ристић 2009: Стана Ристић, Модификачија значења и лексички модификатори у српском језику, Београд: Институт за српски језик САНУ.

PMC 1967: Речник српскохрватског књижевног језика, Нови Сад - Загреб, Матица српска - Матица хрватска.

PCJ 2007: Речник српског језика, Нови Сад: Матица српска.

Силић, Прањковић 2005: J. Silić, I. Pranjković, Gramatika hrvatskoga jezika za gimnazije i visoka učilišta, Zagreb: Školska knjiga.

Симеон 1969: Р. Симеон, Енииклопедијски рјечник лингвистичких назива, Загреб: Матица хрватска.

Станојчић, Поповић 1997: Ж. Станојчић, Љ. Поповић, Граматика српскога језика, уибеник за 1, 2, 3. и 4. разред средње школе, Београд: Завод за уџбенике и наставна средства.

Стевановић 1991: М. Стевановић, Савремени српскохрватски језик I (граматички системи и књижевнојезичка норма), Београд: Научна књига.

Стевановић 1970: М. Стевановић, Савремени српскохрватски језик I (граматички системи и књижевнојезичка норма), Београд: Научна књига. 


\title{
THE RELATION OF THE SUPERLATIVE AND TRANS-SUPERLATIVE IN CONTEMPORARY SERBIAN
}

\begin{abstract}
Summary
The paper discusses the relation between the superlative and trans-superlative at the formal-semantic level. The syntactic morphological superlative, as part of the triadic comparison paradigm, expresses the highest form of a concept's feature or quality only in relation to other concepts, thus a qualification expressed in the superlative does not always have to imply a considerably high degree of presence of the adjectival or adverbial content with regard to a common norm. At the formal level, the trans-superlative is formed syntetically and descriptively: by means of the pre-prefix (pre+positive), by means of the super-prefix/prefixoid (which is also used independently), by means of the lexemes which introduce the meaning of an excessive degree into the adjectival / adverbial phrase, like odviše, odveć, (i)suviše, pretjerano, nadasve, enromno, ekstremno, etc. Unlike the superlative, the transsuperlative always foregrounds an exceptionally high, maximum degree of the quality, but it also bears a mark of a certain semantic differentiation (intensivity and excessiveness), so it is formally and semantically richer, and by the same token more expressive.
\end{abstract}

Keywords: comparison, superlative, trans-superlative, elative, excessive. 